DOI: $10.19195 / 0524-4544.325 .7$

\author{
ANDRZEJ PASEK \\ ORCID: 0000-0001-9468-5204 \\ Uniwersytet Wrocławski \\ andrzej.pasek@uwr.edu.pl
}

\title{
Główne założenia projektów ustaw o odpowiedzialności nieletnich na gruncie prawa karnego, opracowanych w początkach II Rzeczypospolitej
}

Prawie do końca XIX wieku ustawodawstwa poszczególnych państw nie traktowały odrębnie przestępczości nieletnich i sposobów jej zwalczania. Problem ten nie stanowił przedmiotu pogłębionych badań teoretyków prawa, praktyków ani rządów. W konsekwencji przy zwalczaniu przestępczości nie rozróżniano przestępców dorosłych od nieletnich, przewidując jednak wobec tych drugich łagodniejsze kary. Za jedyny środek zwalczania przestępczości nieletnich nadal uważano karę stanowiącą równocześnie odwet za naruszenie chronionego ustawą porządku społecznego i środek poprawczy. Ustawodawcy liczyli bowiem, że cierpienia i niedogodności wynikające z jej wykonania powstrzymają nieletniego przed powrotem do przestępstwa. Tego rodzaju założenia okazały się jednak chybione, ponieważ w rzeczywistości kara izolacyjna nie wpływała na poprawę zachowań nieletnich, a wręcz przeciwnie — ulegali oni negatywnym wpływom starszych przestępców i opuszczali placówki penitencjarne bardziej zdemoralizowani niż przed rozpoczęciem odbywania w nich kary. Nie doceniano, że najskuteczniejszym środkiem zwalczania przestępczości wśród nieletnich będzie wychowywanie opuszczonych i zaniedbanych dzieci. $Z$ tego powodu, mimo stosowania surowych kar, przestępczość nieletnich stale rosła, a dodatkowo znaczący odsetek wśród nich stanowili recydywiści ${ }^{1}$.

${ }^{1}$ A. Czerwiński, Obecny stan ustawodawstwa karnego przeciwko nieletnim w Polsce, Lwów 1933, s. 1-2. 
Od schyłku XIX wieku prawnicy i socjologowie pod wpływem szkoły antropologicznej i socjologicznej, a w opozycji do szkoły klasycznej, zaczęli bliżej rozważać przyczyny przestępczości nieletnich. W wyniku tych refleksji wskazali na związek przyczynowy między przestępczością wśród nieletnich a zaniedbaniem wychowania dzieci opuszczonych i osieroconych. W konsekwencji stopniowo zaczął przeważać pogląd, że kara pozbawienia wolności nie stanowiła odpowiedniego środka zwalczania przestępczości nieletnich, lecz była wręcz szkodliwa. Postulowano, żeby przede wszystkim zapobiegać popełnianiu przestępstw przez nieletnich środkami prewencyjnymi, tworząc zakłady wychowawcze dla dzieci opuszczonych i zaniedbanych. Argumentowano, żeby w wypadku popełnienia przestępstwa przez nieletniego zwracać szczególną uwagę, czy mimo przekroczenia ustawowego wieku poczytalności czynów karalnych był on świadomy skutków swego działania. Przekonywano, żeby nawet wobec tych sprawców, którzy działali ze świadomością i zrozumieniem skutków swojego postępowania, stosować w pierwszej kolejności środki wychowawcze, względnie poprawcze, przez umieszczenie ich w zakładach wychowawczych lub poprawczych, a nie kary pozbawienia wolności².

W ramach formułowania i rozwijania nowych zasad wypracowane zostały dwa odmienne poglądy w sprawie zwalczania przestępczości nieletnich. Pierwszy — radykalny — eliminował karę jako środek zwalczania przestępczości nieletnich do pewnego wieku, zastępując ją całkowicie środkami wychowawczo-poprawczymi, które nie mogły być uważane jako kara ani jako odwet za popełnione przestępstwo. Drugi - umiarkowany — dzielił nieletnich przestępców poniżej pewnego wieku na działających bez rozeznania i działających z rozeznaniem. Wobec tej grupy przewidywano stosowanie $\mathrm{z}$ reguły kary w jej właściwym znaczeniu, ale $\mathrm{z}$ ustawowym łagodzeniem sankcji w stosunku do tych wymierzanych na zasadach ogólnych. Zwolennicy jednej i drugiej koncepcji zgadzali się natomiast, że sprawy nieletnich przestępców powinny podlegać jurysdykcji odrębnych, specjalnych sądów dla nieletnich. Ich zadaniem byłoby nie tylko sądzenie, lecz także stosowanie wobec nieletnich przestępców środków wychowawczych i poprawczych, a w szczególności umieszczanie ich w zakładach wychowawczych lub wychowawczo-poprawczych ${ }^{3}$.

Kodeksy karne państw zaborczych, obowiązujące w Polsce do 31 sierpnia 1932 roku, zawierały różne rozwiązania w zakresie odpowiedzialności karnej nieletnich ${ }^{4}$.

2 Ibidem, s. 2.

3 Ibidem, s. 3.

${ }^{4}$ Zob. szerzej A. Pasek, Systemy odpowiedzialności nieletnich w kodeksach karnych obowiazujących w Drugiej Rzeczypospolitej, [w:] Dziecko i jego pozycja prawna w dziejach, red. A. Pasek, Wrocław 2014, s. 201 n. 
Przepis $\S 2$ lit. d austriackiej ustawy karnej z 1852 roku (a.u.k.) stanowił, że „nie poczyta się za zbrodnię działania lub zaniechania, jeżeli sprawca nie ukończył jeszcze czternastego roku życia"5. Zgodnie z $§ 237$ a.u.k.

czyny karygodne, popełnione przez dzieci do ukończonego dziesiątego roku życia należało pozostawić domowemu tylko skarceniu; ale od rozpoczętego jedenastego do ukończonego czternastego roku życia karze się czyny, których nie poczytuje się tylko z powodu nieletniości sprawcy za zbrodnię (§ 2 lit. d), jako przekroczenia (§ 269 i § 270) ${ }^{6}$.

Na zasadzie $§ 269$ nieletni mogli

w dwojaki sposób stać się winnymi: a) przez czyny karalne, które ze swej właściwości byłyby zbrodniami, ale jeżeli małoletni je popełniają, będą karane według § 237 jako przekroczenia; b) przez takie czyny karalne, które już same przez się są tylko występkami albo przekroczeniami.

Stosownie do $\S 270$ czyny karalne pierwszego rodzaju popełnione przez nieletnich należało karać stosownie do okoliczności zamknięciem w odosobnionym miejscu od jednego dnia do sześciu miesięcy. Karę tę można było „obostrzyć” według § 253 a.u.k. Do okoliczności, jakie należało uwzględnić przy wymierzeniu okresu kary i „obostrzeniu”, § 271 a.u.k. zaliczał: a) wielkość i jakość karygodnego czynu; b) wiek winowajcy; c) jego usposobienie, według samodzielności widocznej tak z popełnionego czynu jak i z uprzedniego zachowania się, według bardziej szkodliwych skłonności, złośliwości albo niepoprawności. Z kolei § 272 wymagał, żeby wykonanie kary w stosunku do nieletniego połączyć ze stosowną pracą i nauką duszpasterza. Natomiast karygodne czyny wskazane w $§ 269$ lit. b popełnione przez nieletnich pozostawiono skarceniu domowemu, a w razie jego braku albo w razie wyłaniających się szczególnych okoliczności, skarceniu i odpowiedniemu zarządzeniu władz bezpieczeństwa ${ }^{7}$.

Austriacki kodeks karny z 1852 roku dzielił zatem nieletnich na trzy grupy: zupełnej nieodpowiedzialności do ukończenia dziesięciu lat, odpowiedzialności zmniejszonej do czternastego roku życia oraz łagodzenia kary od czternastego do dwudziestego roku życia. W drugim okresie zbrodnie karane były jak przekroczenia, a występki i przekroczenia skutkowały jedynie oddaniem rodzicom w celu poprawy domowej lub przekazaniem dziecka władzy politycznej. Sąd w każdym wypadku orzekał, czy oskarżony działał z rozeznaniem. Z chwilą ukończenia czternastu lat rozpoczynał się okres dojrzałości do odpowiedzialności karnej, ale w stosunku do nieletniego, który nie ukończył dwudziestu lat, sąd łagodził karę, o ile nieletni był bliski wieku dziecięcego, miał obniżony poziom inteligencji albo nie otrzymał odpowiedniego wychowania. Zamiast kary śmierci lub ciężkiego,

5 J. Przeworski, Ustawa karna austriacka o zbrodniach, występkach i przekroczeniach z dnia 27 maja 1852 r. obowiąująca w okręgu Sądów Apelacyjnych w Krakowie i we Lwowie oraz Sąu Okręgowego w Cieszynie, Warszawa 1924, s. 13-14.

6 Ibidem, s. 191.

7 Ibidem, s. 204-206. 
dożywotniego więzienia, nieletniemu do lat dwudziestu można było wymierzyć karę ciężkiego więzienia w granicach $10-20$ lat $^{8}$.

Zgodnie z § 55 niemieckiego kodeksu karnego z 1871 roku (n.k.k.) kto dopuszczając się czynu, nie miał ukończonych lat dwunastu, tego nie można było zań ścigać podług prawa karnego. Jednak na podstawie istniejących przepisów można było zastosować odpowiednie środki poprawcze i objąć nieletniego dozorem. Wolno go było umieścić u rodziny, w zakładzie wychowawczym lub poprawczym tylko wówczas, jeżeli sąd opiekuńczy stwierdził uchwałą popełnienie czynu i uznał dopuszczalność takiego umieszczenia. Kolejny $§ 56$ n.k.k. stanowił, że obwinionego, który popełnił przestępstwo po ukończeniu lat dwunastu, ale przed ukończeniem lat osiemnastu, należało uniewinnić, jeżeli popełniając je, nie miał rozeznania potrzebnego do poznania jego karalności. W wyroku należało postanowić, czy obwinionego powierzyć opiece jego rodziny, czy umieścić go W zakładzie wychowawczym lub poprawczym. W zakładzie przebywał dopóty, dopóki przełożona władza administracyjna tego zakładu uznawała to za potrzebne, ale nie dłużej niż „poza ukończony rok dwudziesty”. W myśl § 57 n.k.k. jeżeli obwiniony, który popełnił przestępstwo po ukończeniu lat dwunastu, ale przed ukończeniem lat osiemnastu, miał rozeznanie potrzebne do poznania jego karalności, podlegał następującym zasadom: 1. jeżeli za czyn groziła kara śmierci lub dożywotnie ciężkie więzienie, należało orzec więzienie od lat trzech do piętnastu; 2. jeżeli za czyn groziło dożywotnie osadzenie w twierdzy, należało orzec takie osadzenie od lat trzech do piętnastu; 3. jeżeli za czyn groziło ciężkie więzienie lub inny rodzaj kary, należało wyznaczyć karę pomiędzy najniższym ustawowym wymiarem zagrożonego rodzaju kary a połową najwyższego wymiaru grożącej kary; jeżeli karą w ten sposób oznaczoną było ciężkie więzienie, wówczas zastępowała je kara więzienia na taki sam okres; 4. jeżeli czyn był występkiem lub wykroczeniem, można było w szczególnie lekkich wypadkach orzec naganę; nie należało orzekać utraty wszelkich lub poszczególnych obywatelskich praw honorowych ani dozoru policyjnego'

Niemiecki kodeks karny z 1871 roku oparty był zatem na systemie trzech okresów obejmujących: okres bezwzględnej nieodpowiedzialności, okres odpowiedzialności warunkowej, okres bezwarunkowej odpowiedzialności. System ten zastosowano w większości partykularnych ustaw państw niemieckich i właśnie za ich pośrednictwem przejęty został przez kodeks ogólnoniemiecki z 1871 roku w nieco zmodyfikowanej postaci ${ }^{10}$.

8 A. Mogilnicki, Dziecko i przestępstwo, Warszawa 1925, s. 270-271.

9 J. Kalużniacki, R. Leżański, Kodeks karny obowiąujący na ziemiach zachodnich Rzeczypospolitej Polskiej z uwzględnieniem ustawodawstwa i orzecznictwa Sądu Najwyższego, Warszawa-Poznań 1925, s. 40-42.

10 J. Makarewicz, Prawo karne ogólne, Kraków 1914, s. 108. 
System trzech okresów przyjęty został także w rosyjskim kodeksie karnym z 1903 roku (r.k.k.) ${ }^{11}$. Kodeks ten na gruncie art. 40-41 oraz art. 55 wyróżniał następujące okresy niepełnoletniości: a) od urodzenia do ukończenia lat dziesięciu, b) od lat dziesięciu do siedemnastu, c) od lat siedemnastu do dwudziestu jeden. Przed ukończeniem dziesięciu lat dziecko nie mogło być pociągnięte do odpowiedzialności karnej; można było natomiast zastosować środki zapobiegające dalszemu popełnianiu czynów karalnych. Należało do nich zarówno oddanie pod dozór odpowiedzialny rodziców lub opiekunów, jak i umieszczenie w zakładzie wychowawczo-poprawczym. Nie mógł ich jednak orzec sąd, ponieważ sprawy przeciwko nieletnim do lat dziesięciu nie podlegały jego jurysdykcji. Dzieci do lat dziesięciu były zatem bezwarunkowo nieodpowiedzialne karnie za popełnione czyny, niezależnie od stanu umysłu i w ogóle rozwoju psychicznego. Z kolei nieletni z grupy wiekowej w przedziale 10-17 lat mogli odpowiadać, jeżeli spełniali ogólne warunki poczytalności oraz zostali uznani przez sąd za działających ze zrozumieniem. Wobec pierwszej grupy nie mogło być wszczęte postępowanie karne, wobec nieletnich z drugiej grupy musiało być wszczęte w celu stwierdzenia nie tylko winy, lecz także stopnia rozwoju sprawcy. Jeżeli sąd ustalił, że nieletni z powodu stanu rozwoju psychicznego nie zdawał sobie sprawy z przestępczego charakteru swojego czynu, to uwalniał go od odpowiedzialności, a postępowanie karne umarzał ${ }^{12}$. Jednocześnie sąd mógł oddać nieletniego pod opiekę rodziców lub osób zasługujących na zaufanie, a sprawcę zbrodni lub występku również umieścić w zakładzie wychowawczo-poprawczym. Jeżeli sprawca skończył w chwili popełnienia czynu 14 lat, to $\mathrm{w}$ wypadku zbrodni miał być w miarę możliwości umieszczony w zakładzie wychowawczo-poprawczym, w razie zaś niemożności umieszczenia w takim zakładzie - w specjalnie urządzonych, więziennych oddziałach dla nieletnich. Dziewczęta mogły być umieszczane w klasztorach. Czas pobytu w tych zakładach zależał od decyzji osób nimi kierujących, ale nie mógł trwać dłużej niż do ukończenia osiemnastu lat, a w przypadku nieletnich skierowanych tam w wieku co najmniej piętnastu lat — do ukończenia dwudziestu jeden lat. Jeżeli nieletni sprawca w wieku od dziesięciu do siedemnastu lat został uznany za działającego z należytym rozeznaniem, wówczas odpowiadał według szczególnych zasad ujętych w art. 55 r.k.k. Gdy przestępstwo było głównie wynikiem złego wychowania, a nieletni przestępca rokował poprawę, sąd mógł zamiast wymierzyć karę, umieścić go w zakładzie wychowawczo-poprawczym aż do dwudziestego pierwszego roku życia. Wcześniejsze uwolnienie było możliwe na podstawie decyzji zarządu więziennego w porozumieniu z prokuratorem. Zamknięcie $\mathrm{w}$ więzieniu wymagało wydzielenia osobnego pomieszczenia. W przypadkach mniejszej wagi można było zastosować naganę ${ }^{13}$.

11 Ibidem, s. 109.

12 W. Borowski, Zasady prawa karnego. Część ogólna, Warszawa 1922, s. 98-100.

13 W. Makowski, Prawo karne. Część ogólna. Wykład porównawczy prawa karnego austriackiego, niemieckiego i rosyjskiego obowiązującego w Polsce, Warszawa 1920, s. 235; idem, Kodeks 
Po odzyskaniu przez Polskę niepodległości w 1918 roku utrzymano w mocy dzielnicowe akty prawne państw zaborczych, w tym także regulujące odpowiedzialność karną nieletnich. Ponadto wydany został dekret z 7 lutego 1919 roku $\mathrm{w}$ przedmiocie utworzenia sądów dla nieletnich ${ }^{14}$. Ustanawiał on w art. 2 specjalne sądy pokoju dla nieletnich w Warszawie, Łodzi i Lublinie, które miały rozpoznawać wszelkie sprawy karne, wynikłe na terytorium danego miasta i należące do właściwości sądów pokoju, o ile oskarżonymi lub poszkodowanymi $\mathrm{w}$ tych sprawach byli nieletni w wieku do siedemnastu lat. Przepis art. 2 dekretu przewidywał utworzenie przy sądach dla nieletnich urzędów stałych opiekunów sądowych, mianowanych przez sędziego spośród osób obojga płci, szczególnie kwalifikujących się do sprawowania nadzoru nad nieletnimi. Opiekunom sądowym przysługiwało stałe wynagrodzenie z funduszów dyspozycyjnych sądu, przy wykonywaniu zaś obowiązków podlegali wskazówkom sędziego według instrukcji wydanej przez Ministra Sprawiedliwości. Przy sądach dla nieletnich — jak stanowił art. 3 dekretu - mogły być utworzone specjalne izby przeznaczone dla nieletnich, których pozostawanie na wolności nie było możliwe i którzy mieli w nich przebywać pod dozorem opiekuna sądowego lub osoby wyznaczonej przez sędziego. Organizację sądów dla nieletnich oraz tryb rozpoznawania spraw w tych sądach regulowało rozporządzenie Ministra Sprawiedliwości wydane na podstawie delegacji zawartej $\mathrm{w}$ art. 4 dekretu ${ }^{15}$. Jednak sądów tych nie zorganizowano, a zatem $\mathrm{z}$ tej cząstkowej regulacji w praktyce nie skorzystano ${ }^{16}$.

Przejęty po państwach zaborczych stan prawny dotyczący zasad odpowiedzialności nieletnich wymagał szybkiego ujednolicenia i odpowiedniego uzupełnienia, przy uwzględnieniu nowoczesnych tendencji w doktrynie oraz w ustawodawstwie innych państw ${ }^{17}$.

Do zwolenników wyodrębnienia prawa karnego nieletnich i jego starannego opracowania należał docent Uniwersytetu Jagiellońskiego dr Józef Reinhold, który w 1919 roku opublikował projekt ustawy o młodocianych przestępcach ${ }^{18}$. W kluczowej kwestii wieku autor przyjął, że granicę odpowiedzialności karnej stanowi osiągnięcie czternastego roku życia. Argumentował, że granica ta odpo-

karny obowiąujacy tymczasowo w Rzeczypospolitej Polskiej na ziemiach b. zaboru rosyjskiego $z$ dodaniem: przepisów przechodnich i ustaw, zmieniajacych $i$ uzupetniajacych postanowienia karne kodeksu, odpowiednich przepisów Kodeksu Karnego Niemieckiego i Ustawy Karnej Austriackiej, obowiązujacych w pozostatych dzielnicach Rzeczypospolitej oraz Komentarza i orzeczeń Sąu Najwyższego, t. 1, część ogólna, Warszawa 1921, s. 140-145, 200-204.

14 Dekret z 7 lutego 1919 roku w przedmiocie utworzenia sądów dla nieletnich, Dziennik Praw Państwa Polskiego (Dz.Pr.P.P) 1919, nr 14, poz. 171.

15 Rozporządzenie Ministra Sprawiedliwości z dnia 26 lipca 1919 roku w przedmiocie urządzenia sądów dla nieletnich (Dz.Pr.P.P. 1919, nr 63, poz. 378).

16 A. Czerwiński, op. cit., s. 9.

17 Ibidem.

18 J. Reinhold, Projekt ustawy o młodocianych przestępcach i jego uzasadnienie, „Kwartalnik Prawa Cywilnego i Karnego" II, 1919, odbitka. 
wiada chwili, do której obowiązuje lub powinien obowiązywać przymus szkolny i z którą z reguły rozpoczyna się okres dojrzewania płciowego. W myśl projektu sędzia karny, który z powodu wieku sprawcy zaniechał dalszego ścigania lub sędzia opiekuńczy, którego o przestępstwie nieletniego zawiadomił sąd karny, byli zobowiązani do wydania zarządzeń stosownie do sytuacji. Jeżeli sprawca okazał się niebezpieczny z powodu choroby umysłowej, należało zarządzić jego przetrzymanie w domu leczniczym lub w zakładzie dla umysłowo chorych względnie w odrębnym oddziale takiego domu lub zakładu. Podobnie sędzia zarządzał wychowanie ochronne sprawcy, jeżeli przekonał się, że główną przyczyną popełnienia czynu zabronionego był brak wychowania lub jego zaniedbanie. Wreszcie w razie ustalenia konieczności odizolowania sprawcy od dotychczasowego środowiska możliwe byłoby powierzenie jego wychowania funkcjonującemu w tym celu zakładowi lub rodzinie. Zarządzenia te polegały zatem na zastosowaniu środków ochronnych bezpośrednio w interesie jednostki, a tylko pośrednio w interesie ogółu społeczeństwa. Autor uważał, że ich bliższe unormowanie nie należało do zakresu ustawy karnej, lecz ustawy o wychowaniu ochronnym. Stąd ograniczył się w projekcie do ogólnej dyrektywy pod adresem sędziego w nadziei, że osobna ustawa szczegółowo oznaczy treść tych zarządzeń ${ }^{19}$.

Projekt wprowadził także okres warunkowej poczytalności, zwany również okresem problematycznej poczytalności, od ukończenia czternastego do ukończenia osiemnastego roku życia. Oprócz ogólnych przesłanek wykluczających poczytalność sprawcy projekt J. Reinholda uznawał specyficzną okoliczność wykluczającą poczytalność i odpowiedzialność młodocianego sprawcy — niedojrzałość umysłową lub moralną. Autor wskazywał, że większość ówczesnych ustawodawstw, idąc za wzorem kodeksu francuskiego, kładła nacisk na ustalenie okoliczności, czy sprawca działał z należytym rozeznaniem, uwzględniając w ten sposób zbyt jednostronnie tylko intelektualny rozwój sprawcy. Tymczasem umysłowa dojrzałość polegająca na zdolności rozróżniania między prawem a bezprawiem nie stanowiła wystarczającej podstawy do odpowiedzialności karnej młodego sprawcy. Należało bowiem w równym stopniu uwzględnić dojrzałość moralną, polegającą na zdolności do oparcia się motywom skłaniającym do popełnienia przestępstwa. Autor projektu argumentował, że na rozwój intelektualny i moralny młodocianych negatywnie wpływa brak wychowania lub niedostateczne wychowanie. Taki deficyt powodował z reguły niezrozumienie wartości społecznych jako motywów działania, a zatem postawy, którą właściwe wychowanie domowe lub szkolne stara się przekazać każdemu dziecku. Krakowski uczony zwracał także uwagę, że niemniej ważną rolę w przestępczości młodocianych odgrywały patologiczne stany umysłowe od przytępienia umysłowego do kretynizmu oraz epilepsja czy histeria. $Z$ tych powodów tak mocno akcentował ustawowe uznanie okresu problematycznej dojrzałości, uznając za jej znamiona niedorozwój umy-

19 Ibidem, s. 15-17. 
słowy lub moralny. Niedojrzałości umysłowej odpowiadała niezdolność do zrozumienia istoty i znaczenia popełnionego przestępstwa, niedojrzałość zaś rozwoju moralnego ujawniała się w niezdolności do kierowania swoim postępowaniem. Odnośnie do środków ochronnych, ich charakteru i rodzaju oraz stosowania przez sędziego w razie uwolnienia sprawcy od odpowiedzialności karnej należało stosować zasady dotyczące sprawców, którzy nie ukończyli czternastego roku życia ${ }^{20}$.

Projekt przewidywał możliwość odstąpienia od kary oraz stosowanie warunkowego zawieszenia wykonania kary. Jeżeli młodociany popełnił przestępstwo zagrożone w ustawie grzywną lub karą pozbawienia wolności poniżej sześciu miesięcy, sąd mógł odstąpić od wymierzenia kary, o ile uznał, że sprawca popełnił czyn z nierozwagi, ze swawoli lub z innej pobudki nieświadczącej o zepsuciu lub o moralnym zaniedbaniu. Sąd ograniczał się do stwierdzenia winy w wyroku i udzielał sprawcy upomnienia. Odstąpienie od kary było wykluczone, jeżeli sprawca już raz został uznany winnym czynu przestępczego.

Jeżeli młodociany przestępca nie odbył kary na wolności, a został skazany na karę pozbawienia wolności, nieprzekraczającą sześciu miesięcy, sąd mógł orzec zawieszenie wykonania kary na okres próby, o ile przy uwzględnieniu rodzaju i pobudki czynu, dotychczasowego trybu życia i charakteru sprawcy uznał, że wykonanie kary nie było konieczne do powstrzymania go od dalszych przestępstw.

Jeżeli młodociany popełniał przestępstwo, za które sąd uznałby za właściwe skazać go na grzywnę lub na karę pozbawienia wolności, nie przekraczającą sześciu miesięcy, mógł odstąpić od wymierzenia kary i zarządzić wychowanie sprawcy, o ile tego wymagało jego moralne zaniedbanie lub konieczność poprawy. Pobyt w zakładzie poprawczym mógł trwać najwyżej dwa lata ${ }^{21}$.

Wychowanie poprawcze nie było środkiem karnym, lecz kryminalno-politycznym zarządzeniem dla ochrony społeczeństwa przed przestępczością. O zarządzeniu wychowania poprawczego rozstrzygało nie przestępstwo, lecz stan sprawcy: jego zaniedbanie moralne i konieczność poprawy. Wychowanie poprawcze wstępowało w miejsce kary; projekt hołdował zasadzie absorpcji kary przez środek zabezpieczający. Projekt umożliwiał sędziemu stosowanie wychowania zamiast kary w bardzo szerokich granicach. Kara stanowiła ostateczny środek reakcji państwa wobec przestępczości młodocianych. W sytuacji braku warunków stosowania instytucji odstąpienia od kary lub warunkowego zawieszenia wykonania kary albo zastąpienia kary wychowaniem poprawczym należało zastosować karę jako typową formę reakcji w miejsce indywidualizujących zarządzeń. Projekt jednak wykluczał stosowanie kary śmierci i dożywotniego więzienia. Natomiast można było stosować karę terminowego więzienia i grzywny. Przy wymierzaniu kary więzienia sędzia mógł obniżyć ustawową granicę do sześciu miesięcy ${ }^{22}$.

20 Ibidem, s. 17-19.

21 Ibidem, s. 2-3.

22 Ibidem, s. 29-33. 
Oprócz przepisów materialnych projekt zawierał także postanowienia z zakresu postępowania karnego, a wśród nich pierwszoplanowe znaczenie miały przepisy związane z powołaniem specjalnych sądów dla młodocianych. W ówczesnych ustawodawstwach znane były dwa kierunki o odmiennym spojrzeniu na istotę i ustrój tego rodzaju sądów. Pierwszy traktował to zagadnienie zewnętrznie i formalnie, poprzestając na zmianie podziału czynności w sądzie i przydziale spraw karnych przeciwko młodocianym jednemu oddziałowi sądowemu. Drugi, sięgając głębiej w istotę rzeczy, zmieniał normy ustawowe o właściwości sądów i dążył do utworzenia sądów dla młodocianych o specjalnej obsadzie, o odrębnych kompetencjach, wyraźnie oddzielonych od zwyczajnych sądów karnych. Projekt krakowskiego uczonego, wzorując się na drugim kierunku, przekazywał wszystkie sprawy karne przeciwko młodocianym, bez względu na kwalifikację prawną czynu, jednemu sędziemu. Dotyczyło to także spraw karnych, które w przypadku osób dorosłych rozstrzygane były w składzie kolegialnym. Autor projektu podnosił, że specyficzne zadanie sędziego dla młodocianych, polegające na jak najdalej idącej indywidualizacji, spełni lepiej skład jednoosobowy niż kolegialny. Ponadto zwiększone poczucie odpowiedzialności, możliwość specjalizacji, osobiste przejęcie się sprawą i dążenie do jej wszechstronnego rozpatrzenia zapewniały przewage jednoosobowemu orzecznictwu ${ }^{23}$.

Gwarancję sprawiedliwego wymiaru sprawiedliwości w składzie jednoosobowym stanowiła na gruncie projektu $\mathrm{z}$ jednej strony obligatoryjna obrona dla wszystkich młodocianych, $\mathrm{z}$ drugiej zaś prawo do apelacji od wyroku sądu pierwszej instancji ${ }^{24}$.

Projekt Reinholda przewidywał, że karę pozbawienia wolności poniżej trzech miesięcy młodociany za zezwoleniem sądu mógł odbyć w zakładzie prywatnym. Skazanych młodocianych należało umieścić w osobnych oddziałach więzienia, wykluczając kontakt z dorosłymi. Należało im zapewnić moralno-religijną formację i naukę, w szczególności w rzemiośle i zawodzie, które zapewniłyby im utrzymanie po opuszczeniu zakładu. Młodociany przestępca, który odbył dwie trzecie oznaczonej w wyroku kary pozbawienia wolności, mógł skorzystać z warunkowego uwolnienia od reszty kary, jeżeli na podstawie jego dotychczasowego trybu życia i zachowania w toku wykonywania kary można było przyjąć, że po odzyskaniu wolności nie powróci na drogę przestępstwa. O zastosowaniu warunkowego uwolnienia rozstrzygała okręgowa dyrekcja więzienna, po wysłuchaniu zdania prokuratora apelacyjnego. Okres próby odpowiadał czasowi niewykonanej

23 Józef Reinhold akcentował przy tym znaczenie starannego doboru sędziów dla młodocianych, którzy powinni oprócz doświadczenia życiowego, odpowiedniego przygotowania teoretycznego z dziedziny pedagogiki, psychologii i psychopatologii „w pierwszym rzędzie swój zawód pokochać i oddawać mu się ciałem i duszą". Samo formalne spełnianie obowiązków uważał za niewystarczające; ,zapał i osobiste przejęcie się jednostki swoim zadaniem mogą tylko urzędowi nadać charakter misji społecznej, którą sąd dla młodocianych spełni i spełniać winien”, ibidem, s. 40.

${ }^{24}$ Ibidem, s. 38-40. 
kary, nie mógł jednak trwać krócej niż rok. Warunkowo uwolnionego należało oddać pod dozór ochronny osoby godnej zaufania lub stowarzyszenia. Po korzystnym upływie okresu próby karę uważało się za odbytą w całości. Dyrekcja więzienia zobowiązana była do nawiązania współpracy z towarzystwami opieki nad młodzieżą w celu zapewnienia podopiecznym źródeł uczciwego zarobku ${ }^{25}$.

Projekt Józefa Reinholda nie został bezpośrednio wykorzystany w dalszych pracach ustawodawczych, ponieważ kompleksowe opracowanie problemu odpowiedzialności nieletnich zostało podjęte w ramach działalności Komisji Kodyfikacyjnej Rzeczypospolitej Polskiej funkcjonującej na podstawie ustawy z 3 czerwca $1919 \mathrm{roku}^{26}$.

Nad przygotowaniem projektu zasad odpowiedzialności nieletnich pracowano szczególnie intensywnie, ponieważ na wyraźne życzenie prezydium Komisji Kodyfikacyjnej postanowiono ten fragment ustawy karnej przygotować wcześniej i wprowadzić w życie odrębnie, jeszcze przed ukończeniem projektu kodeksu karnego ${ }^{27}$.

Pracę nad zasadami odpowiedzialności nieletnich rozpoczęła sekcja prawa karnego Komisji Kodyfikacyjnej Rzeczypospolitej Polskiej już podczas VI posiedzenia w dniu 27 czerwca 1920 roku. Referentem projektu został Aleksander Mogilnicki. Przygotował on kwestionariusz, który miał stanowić podstawę opracowania nowych zasad postępowania z nieletnimi ${ }^{28}$.

Przy układaniu projektu w gronie kodyfikatorów konkurowały dwa kierunki znane w doktrynie i uwzględniane w nowszych ustawodawstwach. Zwolennicy bardziej radykalnej reformy opowiadali się za rezygnacją z kary jako środka zwalczania przestępczości wśród nieletnich i zastąpieniem jej wyłącznie środkami wychowawczymi i poprawczymi, wolnymi od pojęcia odwetu. Zwolennicy rozwiązań bardziej ostrożnych, umiarkowanych chcieli utrzymać dla pewnej kategorii nieletnich swoistą karę o charakterze poprawczym, stosowaną nie tylko w celu wychowania i poprawy, lecz także w ramach klasycznego pojęcia odpłaty, wymierzaną w stosunku do wielkości winy. Pierwszy z tych kierunków, przyjęty głównie w Belgii, a ponadto w Anglii, Holandii, krajach skandynawskich, Stanach Zjednoczonych i Australii, odrzucał zupełnie odpowiedzialność karną nieletnich poniżej pewnej, dość wysokiej granicy wieku (lat 15, 16, a nawet 18 i 19). Drugi kierunek, przyjęty między innymi we Francji i na Węgrzech, lecz także

25 Ibidem, s. 8-9.

26 Ustawa z 3 czerwca 1919 roku o Komisji Kodyfikacyjnej (Dz.Pr.P.P. 1919, nr 44 poz. 315). Szerzej o genezie i powstaniu komisji L. Górnicki, Prawo cywilne w pracach Komisji Kodyfikacyjnej Rzeczypospolitej Polskiej w latach 1919-1939, Wrocław 2000, s. 12-19.

27 A. Lityński, Wydziat Karny Komisji Kodyfikacyjnej II Rzeczypospolitej. Dzieje prac nad częścia ogólna kodeksu karnego, Katowice 1991, s. 98.

28 R. Hałas, Zasady odpowiedzialności nieletnich wedlug Juliusza Makarewicza, [w:] Prawo karne w pogladach Profesora Juliusza Makarewicza, red. A. Grześkowiak, Lublin 2005, s. 311-312. Szerzej o przebiegu prac nad zasadami odpowiedzialności nieletnich w ramach Komisji Kodyfikacyjnej A. Lityński, op. cit., s. 98-110. 
w państwach zaborowych - Austrii, Niemczech i Rosji — dzielił nieletnich na działających z rozeznaniem i bez rozeznania: w pierwszej grupie stosowano karę w jej klasycznym znaczeniu, przewidując jej łagodzenie; wobec drugiej grupy dopuszczano stosowanie wyłącznie środków wychowania i poprawy. Obydwa kierunki były reprezentowane podczas obrad zarówno sekcji prawa karnego, jak i wydziału karnego ${ }^{29}$.

Wynikiem intensywnych prac wydziału i sekcji prawa karnego Komisji Kodyfikacyjnej nad zasadami odpowiedzialności nieletnich od czerwca 1920 roku do marca 1921 roku był projekt ustawy o sądach dla nieletnich uchwalony w dniu 21 marca $1921 \mathrm{roku}^{30}$. Został on przedłożony zebraniu ogólnemu Komisji Kodyfikacyjnej w kwietniu 1921 roku. Do projektu wprowadzono pewne zmiany, a następnie ponownie go wydrukowano ${ }^{31}$, a także przetłumaczono na język francuski i udostępniono specjalistom w kraju i za granicą. Uzyskane w tej sprawie opinie były pozytywne. Na wspólnym posiedzeniu wydziału cywilnego oraz podkomisji redakcyjnej wyłonionej przez wydział karny wprowadzono dalsze, przeważnie redakcyjne poprawki. W tej wersji projekt został przyjęty przez zebranie ogólne Komisji Kodyfikacyjnej w dniu 7 grudnia 1921 roku, ogłoszony drukiem ${ }^{32}$, w dniu zaś 22 grudnia przesłany Ministrowi Sprawiedliwości ${ }^{33}$.

Podstawą projektu był podział nieletnich na dwie kategorie. Pierwsza z nich, wyłączona od odpowiedzialności karnej obejmowała: a) nieletnich do lat trzynastu; b) nieletnich od lat trzynastu do siedemnastu, działających bez rozeznania - w razie popełnienia w obu wypadkach czynu karalnego; c) nieletnich do lat siedemnastu, oddających się żebractwu, włóczęgostwu lub nierządowi; d) nieletnich do lat siedemnastu, którzy się źle prowadzili, o ile rodzice nie mogli sobie poradzić z ich wychowaniem i zwracali się do państwa o pomoc. Względem nieletnich działających z rozeznaniem, projekt uznawał odpowiedzialność karną, ale wprowadzał karę swoistą — umieszczenie w zakładzie poprawczym na czas względnie określony z ostatecznym pozostawieniem zarządowi zakładu ustalenia terminu uwolnienia nieletniego w zależności od postępu poprawy. Kara swoista, przyjęta przez projekt jako rezultat kompromisu z jednej strony miała charakter kary dostosowanej do winy sprawcy, z drugiej jednak odpowiadała głównemu celowi ustawy — dążeniu do poprawienia nieletniego i zwrócenia go na drogę uczciwego życia. Temu celowi odpowiadało względne określenie terminu w wy-

29 A. Mogilnicki, op. cit., s. 358.

30 Projekt ustawy o sadach dla nieletnich uchwalony w III czytaniu przez wydziat karny Komisji Kodyfikacyjnej Rzeczypospolitej Polskiej w dniu 21 marca 1921 r., Warszawa 1921.

31 Projekt ustawy o sadach dla nieletnich uchwalony w III czytaniu przez wydziat karny Komisji Kodyfikacyjnej Rzeczypospolitej Polskiej ze zmianami i uzupetnieniami w układzie podkomisji redakcyjnej i z uzasadnieniem, Warszawa 1921.

32 Projekt ustawy o sądach dla nieletnich uchwalony przez Komisję Kodyfikacyjną Rzeczypospolitej Polskiej w dniu 7 grudnia 1921, Warszawa 1921.

33 A. Lityński, op. cit., s. 109-110. 
roku — sędzia ustalał tylko granice kary, uwolnienie zaś skazanego zależało od oceny jego poprawy. Umieszczanie nieletnich w zakładach poprawczych bezterminowo Komisja uznała za niecelowe, aby uniknąć dowolności zarządów zakładów poprawczych. Natomiast $\mathrm{w}$ granicach $\mathrm{z}$ góry oznaczonych przez sąd zarząd mógł podjąć samodzielną decyzję o uwolnieniu wychowanka ${ }^{34}$.

W wypadkach mniejszej wagi, jeżeli ze względu na charakter nieletniego i okoliczności czynu sąd uznał, że zastosowanie środka poprawczego nie jest celowe, mógł odstąpić od umieszczenia go w zakładzie poprawczym pomimo stwierdzenia, że nieletni popełnił z rozeznaniem czyn zabroniony pod groźbą kary. W tym wypadku sąd, jeśli uznał to za potrzebne, mógł zastosować środki wychowawcze. Nieletniemu, który popełnił z rozeznaniem czyn karalny, sąd mógł, o ile uznał to za celowe, zawiesić umieszczenie w zakładzie poprawczym na okres próby od roku do lat trzech, stosując w tym czasie środki wychowawcze. Jeżeli w okresie próby nieletni źle się prowadził, sąd, na wniosek zarządu zakładu wychowawczego, kuratora, ojca, matki lub opiekuna albo z własnej inicjatywy, mógł odwołać zawieszenie i umieścić nieletniego w zakładzie poprawczym ${ }^{35}$. Projekt nie uzależniał zatem odwołania zawieszenia od żadnych formalnych powodów, pozostawiając to dyskrecjonalnej władzy sędziego. Przeważyła również opinia, że dobrodziejstwa zawieszenia umieszczenia w zakładzie poprawczym nie należy stosować w wypadkach popełnienia zbrodni zagrożonych karą śmierci lub dożywotniego więzienia ze względu na ciężar wyrządzonej społeczeństwu krzywdy.

W stosunku do nieletnich, którzy nie podlegali odpowiedzialności karnej, sąd mógł zastosować środki wychowawcze: upomnienie, oddanie rodzicom lub dotychczasowym opiekunom z uprzedzeniem o ich odpowiedzialności, powierzenie osobie godnej zaufania albo towarzystwu patronatu, albo innej instytucji, o ile ta osoba lub instytucja podjęła się wychowania, umieszczenie w odpowiednim zakładzie państwowym albo też w zakładzie prywatnym, który się na to zgodził ${ }^{36}$.

Do prowadzenia spraw nieletnich w zakresie projektowanej ustawy sąd okręgowy wyznaczał na trzy lata jednego lub więcej sędziów oraz jednego lub więcej zastępców. Tak wyznaczeni sędziowie „nosili miano” sędziów dla nieletnich i rozpoznawali sprawy jednoosobowo. Według projektu cała reforma odpowiedzialności nieletnich oparta została na instytucji sędziego dla nieletnich, któremu przypadła w udziale troska zarówno o wychowanie, jak i poprawę zaniedbanej młodzieży. Przy takim założeniu osoba sędziego nabierała kluczowego znaczenia, dlatego funkcje te miały pełnić osoby z odpowiednim doświadczeniem życiowym. Z tego powodu Komisja Kodyfikacyjna uznała, że sprawy nieletnich należy przekazać sądom okręgowym, ponieważ stanowiska sędziów sądów okręgowych

34 Projekt ustawy o sadach dla nieletnich uchwalony przez Komisję Kodyfikacyjna Rzeczypospolitej Polskiej w dniu 7 grudnia 1921..., s. 13.

35 Ibidem, s. 1.

36 Ibidem, s. 2. 
zajmują ,wytrawniejsze już siły, na ogół lepiej uposażone i przeto niedążące do jak najszybszego przeniesienia w inne miejsce". Cała konstrukcja projektu ustawy opierała się na powierzeniu spraw nieletnich sędziemu starszemu, doświadczonemu i wykwalifikowanemu, któremu przyznano szeroką władzę dyskrecjonalną. Projekt ustawy, wprawdzie wzorowany na unormowaniach funkcjonujących już w innych krajach, dla Polski był w znacznej mierze nowym rozwiązaniem. Przekazanie tego rodzaju spraw mniej doświadczonym sędziom mogłoby zatem całą koncepcję wypaczyć, powodując więcej szkód niż pożytku. Ponadto wobec oddania sądom dla nieletnich spraw o wszystkie przestępstwa, a więc także o zarzucane nieletnim najcięższe zbrodnie, Komisja uznała za niemożliwe powierzanie tych najcięższych zbrodni sądom powiatowym, względnie sądom pokoju. Ustanowienie właściwości jednego sądu było zaś możliwe tylko wtedy, gdy był to sąd okręgowy.

Z pojęciem sądu dla nieletnich związana była myśl o wydzieleniu specjalnego pomieszczenia dla tej kategorii podsądnych. Umieszczanie ich w zakładach karnych było nad wyraz szkodliwe i niebezpieczne, zwłaszcza biorąc pod uwagę możliwą niewinność zatrzymanych lub ich działanie bez rozeznania. Dostrzeżono, że istniejący powszechnie przepis o umieszczaniu młodocianych więźniów w oddziałach osobnych, oddzielnie od dorosłych, okazał się w praktyce zupełnie iluzoryczny, we wspólnym bowiem gmachu, przeważnie przepełnionym, przy niedostatecznie wyrobionym zespole służby i niższych funkcjonariuszy, nie sposób uniknąć zetknięcia się młodocianych osobników, zamkniętych w osobnych oddziałach, z gangreną moralną zwykłej ludności więziennej, a ponadto wysoce ujemny był wpływ zwykłych dozorców więziennych, przyzwyczajonych do ostrego i często brutalnego postępowania z dorosłymi więźniami i rzadko umiejących się naginać do wymagań swoistego postępowania z nieletnimi.

Należało zatem uwzględnić zbieżną w tym względzie opinię teoretyków i praktyków o konieczności zupełnego oddzielenia nieletnich od dorosłych przestępców. Stąd projekt stanowił, że przy każdym sądzie dla nieletnich zostanie założone specjalne schronisko dla czasowo zatrzymanych z dodatkowym zastrzeżeniem, że takie schronisko nie może znajdować się w gmachu, w którym przebywają dorośli aresztanci ${ }^{37}$.

Projekt dążył do możliwego uproszczenia postępowania przed sądem dla nieletnich i zabezpieczenia $\mathrm{w}$ jak najszerszym zakresie jego bezpośredniości. $\mathrm{Z}$ tego powodu eliminował śledztwo wstępne i przekazywał sędziemu, który miał wyrokować, całe wstępne przygotowanie sprawy. Pomagać mu w tym powinny, oprócz władz policyjnych, przede wszystkim towarzystwa patronatu nad nieletnimi, zwłaszcza gdy chodziło o wywiady co do warunków materialnych i moralnych nieletniego oraz jego otoczenia. Poza tym sędzia mógł korzystać ze wsparcia innych osób dobrej woli ${ }^{38}$.

37 Ibidem, s. 17-18.

38 Ibidem, s. 19. 
Kodyfikatorzy założyli, że sukces reformy odpowiedzialności karnej nieletnich zależał także od wielkiej i stałej współpracy społeczeństwa i sądu. Judykatura powinna kierować poprawą młodzieży upadłej, społeczeństwo zaś powinno tworzyć ku temu warunki, ponosząc wysiłek nie tylko materialny, lecz także moralny. Uznano, że bez ludzi dobrej woli, którzy zechcą pod kontrolą sądu podjąć się trudu czuwania nad młodzieżą, a nieraz i jej wychowania czy przyjęcia do swojego domu, projektowana reforma mogła się nie udać. Należało zatem dążyć do wynajdywania takich osób i zapewniania im warunków owocnej pracy, a w tym względzie do pierwszoplanowych zadań należało stworzenie sieci towarzystw patronatu nad małoletnimi. Miały one następnie gromadzić potrzebne fundusze, organizować i utrzymywać zakłady wychowawcze i poprawcze, czuwać nad wykonywaniem opieki nad nieletnimi, zapewniać im obronę w sprawach sądowych, wyszukiwać odpowiednich kandydatów na kuratorów nieletnich i w ogóle czynnie pomagać sędziom w wykonywaniu ich trudnych i odpowiedzialnych obowiązków ${ }^{39}$.

Projekt ustawy o sądach dla nieletnich, starannie i wyczerpująco przygotowany przez Komisję Kodyfikacyjną, uwzględniał najnowszy dorobek doktryny prawa i ustawodawstwa. Poszczególne jego przepisy były pod względem rzeczowym celowe, od strony formalnej zaś jasno i zwięźle zredagowane. Dzięki takim walorom projekt trafnie ujmował problem zwalczania przestępczości nieletnich ${ }^{40}$. W osobnych rozdziałach w sposób przejrzysty i syntetyczny unormował środki wychowawcze i poprawcze, odpowiedzialność nieletnich za popełnione przez nich czyny karalne, odpowiedzialność karną osób dorosłych, które wbrew obowiązkowi pieczy nad nieletnimi, świadomie albo z niedbalstwa lub braku dozoru, dopuszczały do popełnienia przez nich czynów wyczerpujących znamiona ustawy karnej lub uprawiania przez nieletnich nierządu albo żebractwa; dalej regulował ustrój i właściwość sądów dla nieletnich, postępowanie w tych sądach i instytucję patronatu nad nieletnimi ${ }^{41}$.

Opracowany przez Komisję Kodyfikacyjną projekt ustawy o sądach dla nieletnich nie został jednak ostatecznie wprowadzony w życie z powodu znacznych wydatków związanych z jego realizacją, w szczególności budową i utrzymaniem zakładów poprawczych i schronisk dla nieletnich. Natomiast przepisy materialne projektu, dotyczące zasad odpowiedzialności karnej nieletnich, niemal w dosłownym brzmieniu przejął kodeks karny z 11 lipca 1932 roku ${ }^{42}$, który wszedł w życie w dniu 1 września 1932 roku $^{43}$.

39 Ibidem, s. 21-22.

40 A. Czerwiński, op. cit., s. 10.

41 Ibidem.

42 Rozporządzenie Prezydenta Rzeczypospolitej z dnia 11 lipca 1932 roku Kodeks karny (Dz.U.R.P. z 1932 r. nr 60, poz. 571 z późn. zm.).

43 A. Czerwiński, op. cit., s. 10-12. 


\section{Bibliografia}

\section{Źródła}

\section{Projekty aktów prawnych}

Projekt ustawy o sądach dla nieletnich uchwalony w III czytaniu przez wydziat karny Komisji Kodyfikacyjnej Rzeczypospolitej Polskiej w dniu 21 marca 1921 r., Warszawa 1921.

Projekt ustawy o sadach dla nieletnich uchwalony w III czytaniu przez wydziat karny Komisji Kodyfikacyjnej Rzeczypospolitej Polskiej ze zmianami i uzupetnieniami w uktadzie podkomisji redakcyjnej i z uzasadnieniem, Warszawa 1921.

Projekt ustawy o sadach dla nieletnich uchwalony przez Komisję Kodyfikacyjna Rzeczypospolitej Polskiej w dniu 7 grudnia 1921, Warszawa 1921.

Reinhold J., Projekt ustawy o młodocianych przestępcach i jego uzasadnienie, „Kwartalnik Prawa Cywilnego i Karnego" II, 1919, odbitka.

\section{Pozaborowe kodeksy karne}

Ustawa karna austriacka o zbrodniach, występkach i przekroczeniach z dnia 27 maja 1852 r. obowiązująca w okręgu Sądów Apelacyjnych w Krakowie i we Lwowie oraz Sądu Okreggowego w Cieszynie. Przełożył na język polski oraz zaopatrzył przeglądem orzecznictwa i ustawodawstwa polskiego J. Przeworski, Warszawa 1924.

Kodeks karny obowiazujący na ziemiach zachodnich Rzeczypospolitej Polskiej z uwzględnieniem ustawodawstwa i orzecznictwa Sądu Najwyższego, oprac. J. Kałużniacki i R. Leżański, Warszawa-Poznań 1925.

Kodeks karny obowiazujący tymczasowo w Rzeczypospolitej Polskiej na ziemiach b. zaboru rosyjskiego z dodaniem: przepisów przechodnich i ustaw, zmieniających i uzupetniających postanowienia karne kodeksu, odpowiednich przepisów Kodeksu Karnego Niemieckiego i Ustawy Karnej Austriackiej, obowiązujących w pozostalych dzielnicach Rzeczypospolitej oraz Komentarza i orzeczeń Sądu Najwyższego, t. 1. Część ogólna, oprac. W. Makowski, Warszawa 1921.

\section{Akty prawne}

Dekret z 7 lutego 1919 roku w przedmiocie utworzenia sądów dla nieletnich (Dz.Pr.P.P 1919 nr 14, poz. 171).

Rozporządzenie Ministra Sprawiedliwości z 26 lipca 1919 roku w przedmiocie urządzenia sądów dla nieletnich (Dz.Pr.P.P. $1919 \mathrm{nr}$ 63, poz. 378).

Ustawa z 3 czerwca 1919 roku o Komisji Kodyfikacyjnej (Dz.Pr.P.P. 1919 nr 44, poz. 315).

Rozporządzenie Prezydenta Rzeczypospolitej z 11 lipca 1932 roku Kodeks karny (Dz.U.R.P. z 1932 r. nr 60, poz. 571 z późn. zm.). 


\section{Literatura}

Borowski W., Zasady prawa karnego. Część ogólna, Warszawa 1922.

Czerwiński A., Obecny stan ustawodawstwa karnego przeciwko nieletnim w Polsce, Lwów 1933.

Górnicki L., Prawo cywilne w pracach Komisji Kodyfikacyjnej Rzeczypospolitej Polskiej w latach 1919-1939, Wrocław 2000.

Hałas R., Zasady odpowiedzialności nieletnich wedtug Juliusza Makarewicza, [w:] Prawo karne w pogladach Profesora Juliusza Makarewicza, red. A. Grześkowiak, Lublin 2005.

Lityński A., Wydzial Karny Komisji Kodyfikacyjnej II Rzeczypospolitej. Dzieje prac nad częścia ogólna kodeksu karnego, Katowice 1991.

Makarewicz J., Prawo karne ogólne, Kraków 1914.

Makowski W., Prawo karne. Część ogólna. Wykład porównawczy prawa karnego austriackiego, niemieckiego i rosyjskiego obowiazujacego w Polsce, Warszawa 1920.

Mogilnicki A., Dziecko i przestęstwo, Warszawa 1925.

Pasek A., Systemy odpowiedzialności nieletnich $w$ kodeksach karnych obowiązujących w Drugiej Rzeczypospolitej, [w:] Dziecko i jego pozycja prawna w dziejach, red. A. Pasek, Wrocław 2014.

\section{The main principles of draft legislation concerning juvenile liability under criminal law formulated at the beginning of the Second Polish Republic}

\section{Summary}

The paper is devoted to the main principles of draft legislation concerning juvenile liability under criminal law formulated in the early days of the Second Polish Republic. The author discusses the most important legal terms and constructs of the drafts formulated by Józef Reinhold and the Codification Commission of the Republic of Poland.

He demonstrates that juvenile liability under criminal law was presented in a concise and clear manner in the draft regulations, with the legislators reaching a compromise over the latest views of the proponents of the legal doctrine at the time and making a creative use of the solutions used in other countries as well as these countries' experiences. The aim of the Polish proposals was, first of all, to reform the juvenile offenders and not to put them in prison. The reform of criminal law applying to juveniles was meant to formulate special legal regulations as well as an autonomous adjudication procedure. It should be emphasised that the suggestions formulated in the Polish legal doctrine and legislation in the inter-war period were taken into account in the Polish Criminal Code of 1932 and still constitute the basis for dealing with juveniles committing criminal offences.

Keywords: juvenile, draft, criminal liability, Codification Commission 


\section{Hauptgrundsätze der zu Beginn der Zweiten Polnischen Republik ausgearbeiteten Gesetzesvorschläge betreffend die strafrechtliche Verantwortung Minderjähriger}

\section{Zusammenfassung}

Die Bearbeitung betrifft die Hauptgrundsätze der Projekte betreffend die strafrechtliche Verantwortung von Minderjährigen, die in den Anfängen der Zweiten Polnischen Republik ausgearbeitet wurden. Besprochen wurden die wichtigsten Begriffe und Rechtskonstruktionen des Projektes von Józef Reinhold und der Kodifikationskommission der Republik Polen.

Es wurde bewiesen, dass die strafrechtliche Verantwortung von Minderjährigen in den polnischen Entwürfen synthetisch und durchsichtig ausgedrückt wurde. Sie berücksichtigten auch die neusten Meinungen der damaligen Doktrin des Strafrechtes und nutzten kreativ die entsprechenden Lösungen und Erfahrungen anderer Staaten. Das Ziel der in Polen ausgearbeiteten Lösungen war die Besserung der minderjährigen Straftäter und nicht ihre Bestrafung mit dem Freiheitsentzug. Die Reform des Strafrechtes für Minderjährige führte zur Aussonderung spezieller rechtlicher Regulierungen und einer autonomen Entscheidungsart. Zu betonen ist, dass die in der polnischen Rechtslehre und in der Gesetzgebung zu den Anfängen der Zwischenkriegszeit des 20. Jahrhunderts ausgearbeiteten Forderungen in dem polnischen Strafgesetzbuch aus dem Jahre 1932 berücksichtigt wurden und weiterhin eine Verfahrensgrundlage bei straffälligen Minderjährigen darstellen.

Schlüsselworte: Minderjährige, Entwurf, strafrechtliche Verantwortung, Kodifikationskommission 